\title{
PENGARUH IKLAN DI MEDIA SOSIAL INSTAGRAM TERHADAP MINAT BELI MASYARAKAT PADA E-COMMERCE
}

Erick Hartawan, Delfin Liu, Marc Richardo Handoko, Geraldo Evan, Handyanto Widjojo Universitas Prasetiya Mulya

A R T I C L E I N F O

Keywords:
commerce,
information

Kata Kunci: Instagram, ecommerce, promosi, gambar, informasi

Corresponding author:

Handyanto Widjojo handy@pmbs.ac.id

Abstract: In line with the development of Instagram usage as social media, many companies advertise their offerings through Instagram to build consumers' purchase intention through ecommerce. This research aims to explore and identify the factors on Instagram ads that significantly influence purchase intention on e-commerce. Mixed-methods are conducted through interviews, focus group discussion, literature review, and survey. The findings show that promotion, image, and information on Instagram significantly influence purchase intention through e-commerce. The e-commerce companies could benefit from the research findings to optimize their marketing communicationand increase the e-commerce transaction.

Abstrak: Dengan semakin berkembangnya penggunaan Instagram sebagai media sosial, maka banyak perusahaan yang memasang iklan pada Instagram untuk membangun keinginan membeli konsumen. Penelitian ini bertujuan menggali faktorfaktor pada iklan di Instagram yang mempengaruhi minat membeli melalui e-commerce. Pendekatan mixed-methods dilakukan melalui wawancara, focus group discussion, tinjauan pustaka, dan survey. Hasil penelitian ini menunjukkan pengaruh faktor promosi, gambar dan informasi pada iklan di Instagram terhadap intensi pembelian melalui e-commerce. Perusahaan e-commerce dapat meningkatkan transaksi e-commerce dengan mengoptimalkan faktor-faktor tersebut dalam strategi komunikasi pemasarannya. 


\section{PENDAHULUAN}

Perkembangan teknologi yang cepat di Indonesia saat ini banyak memengaruhi berbagai aspek dalam kehidupan, salah satunya di bidang ekonomi. Salah satu bentuk inovasi yang merevolusi cara berbelanja secara daring adalah hadirnya platform e-commerce. Platform e-commerce merupakan sebuah sistem yang dikembangkan untuk kegiatan jual beli melalui internet. Platform e-commerce berkembang dengan sangat cepat di Indonesia karena kemudahan serta biaya pengoperasian yang murah. Indonesia merupakan negara dengan jumlah transaksi e-commerce terbesar di Asia Tenggara yang diperkirakan akan terus naik sampai dengan tahun 2025 (Bisnis.com, 2020; Lidwina, 2019). Terjadinya pandemi COVID-19 membuat pemerintah Indonesia mengeluarkan Peraturan Menteri Kesehatan yang berisi pedoman pembatasan sosial berskala besar yang membatasi masyarakat Indonesia beraktivitas di luar rumah dan membuat platform e-commerce menjadi pilihan utama bagi orang-orang yang ingin tetap berbelanja di tengah situasi pandemi saat ini (Bisnis.com, 2020b). Melihat pertumbuhan e-commerce yang begitu pesat, banyak pengusaha-pengusaha kecil maupun besar yang menjual produknya melalui platform e-commerce seperti Tokopedia, Shopee, Blibli, Lazada, dan Bukalapak (CNN Indonesia, 2021). Akibatnya, persaingan yang ketat terjadi antar penjual untuk mengiklankan dan mempromosikan produknya agar terlihat menarik bagi target konsumen.

Pada era kini, hampir semua orang yang hidup di perkotaan memiliki smartphone dan memiliki akses terhadap internet, sehingga banyak perusahaan yang mempromosikan dan menjual produknya melalui internet. Media yang saat ini sangat berkembang di Indonesia adalah media sosial Instagram yang digunakan oleh lebih dari 60 juta pengguna di Indonesia (Kominfo, 2021). Oleh karena itu, media yang paling sering digunakan oleh perusahan adalah media sosial Instagram. Ada berbagai alasan mengapa instagram merupakan media yang tepat untuk mempromosikan/menjual produk. Pertama, perusahaan dapat menunjukkan foto/video dari produknya beserta deskripsi singkat yang dapat digunakan untuk menjelaskan produk yang ditawarkan. Selain itu, Instagram juga memiliki fitur Instagram ads yang sudah ada sejak Oktober 2013, fitur ini khusus ditujukan untuk bisnis-bisnis yang ingin mempromosikan produknya. Pada dasarnya, terdapat 5 bentuk iklan yang disediakan oleh instagram yaitu Story ads, Photo ads, Video ads, Carousel ads, dan Explore ads. Fitur di Instagram ads ini juga dapat mempromosikan produk berdasarkan lokasi, demografi, minat, dan perilaku (Instagram, 2021).

Beberapa studi terdahulu tentang hubungan Instagram dan intensi penjualan telah dilakukan oleh beberapa peneliti. Beberapa faktor yang berpengaruh teridentifikasi pada hasil studi tersebut, seperti pentingnya pesan, grup sosial, dan kemudahan penggunaan (Amornpashara, Rompho, \& Phadoongsitthi, 2015), persepsi resiko (Gunawan \& Huarng, 2015), iklan berbayar (Evans, Pua, Lim, \& Jun, 2017), kepercayaan konsumen (Astuti \& Putri, 2018), visualisasi pada Instagram (Valentini, Romenti, Murtarelli, Pizzetti, 2018; Teo, Leng, \& Phua, 2019), kredibilitas influencer (Sokolova \& Kefi, 2020), persepsi terhadap sosial media (Copeland \& Zhao, 2020), aktivitas pada media sosial (Aji, Nadhila, \& Sanny, 2020). Namun, sejauh ini belum ada penelitian yang meneliti secara khusus tentang fitur dan konten pada Instagram yang berasal dari studi eksploratori yang melibatkan pengguna Instagram terhadap minat membeli melalui e-commerce.

Mempertimbangkan peran e-commerce dalam dunia bisnis, penelitian ini bertujuan menganalisis atribut atau fitur pada iklan di Instagram yang memengaruhi niat beli konsumen di Jabodetabek melalui e-commerce saat melihat iklan di media sosial Instagram. Hasil penelitian ini 
diharapkan dapat memberikan gambaran bagi perusahaan e-commerce dalam merancang iklan yang efektif melalui Instagram yang paling sesuai dengan produk yang ditawarkan sehingga dapat meningkatkan penjualan. Dengan demikian penelitian ini dapat menjawab pertanyaan penelitian sebagai berikut:

- Faktor-faktor apa yang memengaruhi niat beli konsumen di Jabodetabek melalui $e$ commerce setelah melihat iklan di Instagram?

- Manakah faktor yang paling utama pada iklan di Instagram dalam memengaruhi minat beli konsumen di Jabodetabek melalui e-commerce?

Menurut Kotler dan Keller (2016), media sosial merupakan sebuah media berbasis internet yang dapat digunakan oleh masyarakat atau konsumen untuk membagikan berbagai hal, seperti teks, gambar, suara atau audio, maupun video kepada orang lain. Media daring memiliki perbedaan dengan media konvensional, seperti radio, televisi, media cetak atau media masa, karena memiliki cakupan atau jangkauan yang luas dan tidak dikelola oleh satu pihak saja, sehingga para pelaku bisnis dapat terhubung satu dengan yang lain dengan mudah untuk membangun co-creation (Rolland \& Parmentier, 2013).

Menurut Kotler dan Keller (2016), iklan memiliki beberapa sifat mendasar, yaitu memberikan informasi atau pesan yang dilakukan secara berulang melalui gambar dan suara yang dapat memengaruhi dan menarik perhatian konsumen. Informasi atau pesan yang sesuai dapat membangun kerpercayaan konsumen yang mendorong minat membeli (Copeland \& Zhao, 2020; Amornpashara, Rompho, \& Phadoongsitthi, 2015).

Foto atau gambar produk memberikan visualisasi produk dan membantu pembeli untuk mengetahui produk yang akan dibeli. Visualisasi produk yang baik membangun persepsi kualitas dan mendorong minat membeli (Teo, Leng, \& Phua, 2019) dan gambar memiliki pengaruh yang kuat dari sekedar kumpulan kata-kata serta memberikan deskripsi yang lebih cepat dalam mendorong konsumen untuk membeli produk (Lee, Lee, Moon, \& Sung, 2015). Hubungan emosional yang dibangun secara visual juga berpengaruh terhadap intensi pembelian (Valentini, Romenti, Murtarelli, Pizzetti, 2018).

Kudeshia \& Kumar (2017) menunjukkan bahwa audio, gambar, film dan foto merupakan konten dari media sosial yang dapat menjadi word-of-mouth dan berpengaruh terhadap minat untuk membeli. Hal yang serupa juga dijumpai pada hasil penelitian Zhu, Li, Wang, He, \& Tian (2020) bahwa audio, text, dan visual dapat membangun kepercayan konsumen dan mendorong pembelian produk.

Harga menggambarkan persepsi kualitas dan manfaat yang dapat menjadi pertimbangan konsumen untuk membeli suatu produk (Lee \& Workman, 2021; Klabi, 2020). Harga yang tercantum pada Instagram memungkinkan konsumen untuk menyesuaikan diri terhadap anggaran belanjanya dan memperoleh harga kompetitif yang dapat meningkatkan keinginan untuk membeli (Konstantopoulou, Rizomyliotis, Konstantoulaki, \& Badahdah, 2019).

Promosi merupakan salah satu kegiatan pemasaran yang berkaitan dengan penawaran harga yang menarik dan memberikan stimulus pemasaran yang dapat mendorong minat beli (Erdoğmuş \& Tatar, 2015). Adanya reward (hadiah), seperti adanya poin atau kupon potongan 
harga bagi konsumen juga dapat mempengaruhi minat membeli dalam daring group buying (Chiu, Chen, Du, \& Hsu, 2018).

Menurut Kotler dan Keller (2016), minat beli konsumen merupakan sebuah tingkah laku yang muncul karena adanya dorongan keinginan untuk membeli suatu produk berdasarkan pengalaman konsumen dalam memakai atau membeli suatu produk.

Menurut Indonesian E-Commerce Association (IdEA, 2019), media sosial menjadi platform unggulan untuk melakukan sebuah transaksi di e-commerce. Facebook dan Instagram mengambil peran sebanyak 66\% sebagai media sosial yang mendorong transaksi secara daring. Survey yang dilakukan terhadap sekitar 2.000 pelaku UMKM di 10 kota di Indonesia menunjukkan bahwa hanya sebagian kecil pedagang mikro yang menggunakan platform marketplace untuk sarana dalam bertransaksi dan lebih banyak mengandalkan media sosial untuk berjualan.

Model penelitian ini melibatkan lima variabel independen yaitu informasi, gambar, audio, harga, dan promosi yang muncul pada saat penelitian eksploratori serta diperkuat dengan kalian pustaka yang mendukung hipotesis, sedangkan minat membeli melalui e-commerce merupakan variabel dependen.

Model penelitian tersebut dikembangkan melalui penelitian eksploratori dan studi pustaka yang menghasilkan beberapa hipotesis sebagai berikut:

- $\mathrm{H} 1$ = Informasi pada iklan di media sosial Instagram berpengaruh nyata terhadap minat beli konsumen melalui e-commerce di daerah Jabodetabek.

- $\mathrm{H} 2$ = Gambar pada iklan di media sosial Instagram berpengaruh nyata terhadap minat beli konsumen melalui e-commerce di daerah Jabodetabek.

- $\quad$ H3 = Audio pada iklan di media sosial Instagram berpengaruh nyata terhadap minat beli konsumen melalui e-commerce di daerah Jabodetabek.

- $\mathrm{H} 4$ = Harga produk berpengaruh nyata terhadap minat beli konsumen melalui e-commerce di daerah Jabodetabek.

- $\mathrm{H} 5$ = Promosi pada iklan di media sosial Instagram berpengaruh nyata terhadap minat beli konsumen melalui e-commerce di daerah Jabodetabek.

\section{METODE PENELITIAN}

Penelitian ini menggunakan pendekatan metode campuran (mixed-methods). Penelitian kualitatif dilakukan untuk menggali atribut dan fitur iklan dalam Instagram yang mempengaruhi minat pembeli melalui e-commerce. Interview dan focus group discussion dilakukan dengan melibatkan 10 informan. Tinjauan pustaka dilakukan untuk mengidentifikasi penelitian yang telah dilakukan terkait dengan topik tersebut, mencari gap penelitian, dan menemukan tinjauan pustaka untuk membangun hipotesis. Teknik penelitian kuantitatif yang digunakan adalah survey dengan menyebarkan kuesioner dengan Google Form.

Responden dipilih dengan menerapkan teknik pengambilan sampel non probability, yaitu judgmental sampling dengan kriteria berdomisili di Jabodetabek dan pengguna media sosial 
Instagram, pernah melihat iklan di Instagram dan melakukan transaksi di e-commerce dalam satu bulan terakhir.

Penelitian ini dilakukan pada bulan Oktober hingga Desember 2020. Pengukuran indikator menggunakan skala Likert, dimana 1= Sangat Tidak Setuju (STS), 2= Tidak Setuju (TS), 3= Netral (N), 4= Setuju (S), 5= Sangat Setuju (SS).

Data terkumpul yang berasal dari 212 responden diolah dengan menggunakan software Statistical Package for Social Science (SPSS) untuk mengetahui tingkat reliabilitas dan validitas data. Pengaruh variabel independen terhadap variabel dependen dianalisis dengan regresi linier, sedangkan perbedaan persepsi antar kategori responden dilakukan dengan analisis uji beda menggunakan independent sample T- test dan one-way Anova.

\section{HASIL DAN PEMBAHASAN}

\subsection{Profil responden}

Pengumpulan data responden menghasilkan 212 data set yang dapat diolah atau sebesar $65.1 \%$ dari total data 250 responden. Responden adalah mahasiswa wanita (65.1\%) dan pria (34.9\%), yang umumnya berusia 18-22 tahun (99.1\%) dan berdomisili di Tangerang (43.4\%), Jakarta (40.6\%), dan kota-kota lainnya di seputar Jabodetabek.

Tabel 1. Profil Responden

\begin{tabular}{lcc}
\hline & Frekuensi & Persentase \\
\hline Jenis Kelamin & & \\
\hline Pria & 74 & $34.9 \%$ \\
Wanita & 138 & $65.1 \%$ \\
\hline Usia & & \\
\hline$<18$ & 2 & $0.9 \%$ \\
$18-22$ & 210 & $99.1 \%$ \\
\hline Domisili & & \\
\hline Jakarta & 86 & $40.6 \%$ \\
Bogor & 19 & $9 \%$ \\
Tangerang & 92 & $43.4 \%$ \\
Depok & 2 & $0.9 \%$ \\
Bekasi & 13 & $6.1 \%$ \\
\hline Sumber: Hasil pengolahan & SPSS & \\
\hline
\end{tabular}

Sumber: Hasil pengolahan SPSS (2020)

\subsection{Validitas dan realiabilitas}

Uji validitas memastikan alat ukur atau indikator yang digunakan mengukur variabel dengan benar, yang ditunjukkan dengan angka KMO dan component matrix di atas 0.5. Reliabilitas 
menggambarkan konsistensi hasil pengujian indikator yang digunakan bila dilakukan pengulangan penelitian, yang ditunjukkan dengan nilai Cronbach's Alpha $>0.7$.

Berdasarkan hasil uji validitas, component matrix dari setiap indikator dan nilai KMO masing-masing variabel menunjukkan angka di atas 0.5, sehingga dapat disimpulkan bahwa data yang diperoleh memiliki validitas yang baik. Nilai Cronbach's Alpha dari setiap variabel juga menunjukkan angka di atas 0.7 yang berarti memiiki tingkat reliabilitas yang baik.

Tabel 2. Tabel Hasil Uji Validitas dan Reliabilitas

\begin{tabular}{|c|c|c|c|}
\hline \multirow[b]{2}{*}{ Variable/Items } & \multicolumn{2}{|c|}{ Validitas } & \multirow{2}{*}{$\begin{array}{c}\text { Reliabilitas } \\
\text { Cronbach's } \\
\text { Alpha }\end{array}$} \\
\hline & $\begin{array}{c}\text { Componen } \\
\text { t Matrix }\end{array}$ & $\mathrm{KMO}$ & \\
\hline Informasi & & 0.697 & 0.804 \\
\hline - Informasi yang mudah dimengerti & 0.781 & & \\
\hline - Informasi yang mudah diingat & 0.697 & & \\
\hline $\begin{array}{l}\text { - Informasi yang mendeskripsikan produk } \\
\text { secara mendetail }\end{array}$ & 0.688 & & \\
\hline Gambar & & 0.823 & 0.815 \\
\hline - Gambar yang terlihat jelas & 0.767 & & \\
\hline - Visualisasi yang menarik & 0.675 & & \\
\hline - Warna gambar yang 'eye-catching' & 0.825 & & \\
\hline - Adanya logo e-commerce pada gambar & 0.597 & & \\
\hline - Tampilan endorser yang menarik & 0.697 & & \\
\hline - $\quad$ Animasi gambar yang menarik & 0.802 & & \\
\hline Audio & & 0.745 & 0.897 \\
\hline - Suara yang jelas terdengar & 0.869 & & \\
\hline - Audio mendeskripsikan produk yang sesuai & 0.871 & & \\
\hline - $\quad$ Lagu yang mudah diingat & 0.875 & & \\
\hline - $\quad$ Efek suara yang bagus & 0.884 & & \\
\hline Harga & & 0.772 & 0.855 \\
\hline - Harga sesuai kualitas & 0.867 & & \\
\hline - Harga sesuai manfaat & 0.830 & & \\
\hline - Harga sesuai anggaran belanja & 0.854 & & \\
\hline - $\quad$ Harga yang bersaing & 0.797 & & \\
\hline Promosi & & 0.629 & 0.689 \\
\hline - $\quad$ Hadiah (reward) yang menarik & 0.725 & & \\
\hline - Adanya potongan harga & 0.853 & & \\
\hline - Tawaran kode promo & 0.785 & & \\
\hline Minat Beli Konsumen & & 0.729 & 0.812 \\
\hline - Saya berminat membeli lewat e-commerce & 0.789 & & \\
\hline - Saya terdorong membeli melalui e-commerce & 0.819 & & \\
\hline $\begin{array}{l}\text { - Saya ingin melakukan pembelian melalui } e \text { - } \\
\text { commerce }\end{array}$ & 0.828 & & \\
\hline $\begin{array}{l}\text { - Saya akan melakukan pembelanjaan lewat } e \text { - } \\
\text { commerce dalam waktu dekat }\end{array}$ & 0.777 & & \\
\hline
\end{tabular}


Sumber: Hasil pengolahan SPSS (2020)

Analisis regresi linear ini bertujuan untuk mengetahui tingkat pengaruh masing-masing independent variabel, yaitu informasi (X1), gambar (X2), audio (X3), harga (X4), dan promosi (X5) pada media sosial terhadap variabel dependen yaitu minat beli pada e-commerce (Y).

Variabel informasi (X1) menunjukkan nilai signifikan sebesar $0.026(<0.05)$ dengan koefisien beta sebesar 0.154 . Hal ini menunjukkan bahwa variabel informasi berpengaruh positif terhadap minat beli secara nyata (H1 diterima).

Tabel 3. Tabel Analisa Hasil Regresi

\begin{tabular}{|l|c|c|}
\hline \multicolumn{1}{|c|}{ Variabel } & $\begin{array}{c}\text { Standardized } \\
\text { Coefficient }\end{array}$ & Sig \\
\hline Informasi & 0.154 & 0.026 \\
\hline Gambar & 0.225 & 0.003 \\
\hline Audio & 0.002 & 0.974 \\
\hline Harga & 0.060 & 0.363 \\
\hline Promosi & 0.424 & 0.000 \\
\hline R square & \multicolumn{2}{|c|}{$\mathbf{0 . 7 3 8}$} \\
\hline
\end{tabular}

Sumber: Hasil pengolahan SPSS (2020)

Variabel gambar (X2) menunjukkan nilai signifikan sebesar $0.003(<0.05)$ dengan koefisien beta sebesar 0.225. Hal ini menunjukkan bahwa variabel gambar berpengaruh positif terhadap minat beli secara nyata (H2 diterima).

Variabel audio (X3) menunjukkan nilai signifikan sebesar $0.974(>0.05)$ sehingga dapat disimpulkan bahwa audio tidak berpengaruh secara nyata terhadap minat beli (H3 ditolak). Demikian juga variabel harga (X4) menunjukkan nilai signifikan sebesar $0.363(>0.05)$ sehingga dapat disimpulkan bahwa variabel harga tidak berpengaruh nyata terhadap minat beli (H4 ditolak).

Variabel promosi (X5) menunjukkan nilai signifikan sebesar $0.000(<0.05)$ dan koefisien beta sebesar 0.424 . Hal ini menunjukkan bahwa variabel promosi berpengaruh positif terhadap minat beli secara nyata (H5 diterima).

Koefisien R kuadrat pada hasil uji regresi linear adalah 0.738 yang berarti $73.8 \%$ variabel minat beli dapat dijelaskan dan dipengaruhi oleh variabel-variabel independent informasi, gambar, audio, harga dan promosi, sedangkan $26.2 \%$ sisanya dipengaruhi oleh variabel lain yang belum termasuk pada penelitian ini.

Hasil independent t-test menunjukkan tidak ada perbedaan pengaruh informasi, gambar, harga, audio dan promosi antara responden pria dan wanita. Namun responden wanita menunjukkan minat membeli melalui e-commerce yang lebih tinggi daripada responden pria (mean=4.1304 $>3.9189$, sig.2-tailed $=0.030)$.

Hasil uji one-way Anova menunjukkan adanya perbedaan pengaruh audio antara responden dari berbagai lokasi domisili. Peranan audio pada Instagram terhadap minat beli 
responden yang berada di daerah sekitar Jakarta menunjukkan nilai yang lebih tinggi daripada bagi responden yang tinggal di Jakarta (sig=0.002).

\subsection{Pembahasan}

Hasil uji regresi linear menunjukkan bahwa informasi pada media sosial Instagram berpengaruh secara nyata terhadap minat beli konsumen di platform e-commerce. Selain itu, informasi berpengaruh secara positif terhadap minat beli konsumen yang berarti semakin baik informasi yang tersedia pada iklan maka semakin tinggi minat beli konsumen. Semakin berkualitas informasi yang terdapat pada iklan instagram, konsumen semakin berminat untuk membeli produk di $e$ commerce. Informasi yang berkualitas mencakup informasi yang mudah dimengerti, mudah diingat, dan juga dapat mendeskripsikan barang secara detail.

Temuan lainnya adalah tampilan gambar pada media sosial Instagram berpengaruh positif secara nyata terhadap minat beli konsumen di platform e-commerce. Hal ini berarti semakin baik gambar pada iklan di media sosial, semakin tinggi juga minat beli konsumen. Gambar yang jelas, visualisasi atau animasi yang menarik, tampilan endorser dan komposisi warna yang baik pada Instagram dapat meningkatkan minat beli konsumen melalui e-commerce.

Promosi pada media sosial Instagram juga berpengaruh positif secara nyata terhadap minat beli konsumen di platform e-commerce. Di antara variabel berpengaruh lainnya, variabel promosi menunjukkan pengaruh paling kuat, ditunjukkan oleh nilai $\beta$ yang lebih tinggi daripada gambar dan informasi $(\beta=0.424>0.225$ dan 0.154). Promosi tersebut dapat berupa membagikan kode promo untuk menarik konsumen baru, menawarkan potongan harga atau memberikan hadiah agar konsumen tertarik untuk berbelanja dengan jumlah yang lebih banyak.

Secara umum, wanita memiliki niat membeli melalui platform e-commerce yang lebih tinggi dibandingkan pria. Beberapa penelitian sebelumnya menunjukkan bahwa pembelian melalui e-commerce dipengaruhi tampilan, opini, dan rekomendasi pada Instagram dapat mendorong niat membeli bagi wanita (Djafarova \& Bowes, 2021; Loureiro \& Sarmento, 2018).

Walaupun audio pada Instagram tidak berpengaruh terhadap niat beli melalui e-commerce, namun peranan audio terlihat lebih tinggi pada pendengar dari Depok, Bekasi, Bogor, dan Tangerang daripada Jakarta. Hal ini disebabkan pola hidup yang berbeda antara pendengar di Jakarta dengan daerah sekitarnya. Pola hidup yang serba cepat dan pekerjaan yang lebih menuntut tampaknya membuat pengguna media sosial Instagram di Jakarta kurang memperhatikan audio yang biasanya membutuhkan waktu untuk mendengar dan menikmatinya, sehingga lebih dipengaruhi promosi, gambar, dan informasi yang lebih menarik perhatian secara cepat dan langsung dapat ditangkap secara visual.

\section{SIMPULAN DAN SARAN}

Hasil penelitian ini menunjukkan bahwa informasi, gambar, dan promosi pada media sosial Instagram dapat meningkatkan minat beli konsumen melalui e-commerce di daerah Jabodetabek. Promosi merupakan faktor paling berpengaruh terhadap minat beli konsumen dibandingkan gambar dan informasi, sedangkan audio dan harga tidak berpengaruh terhadap minat membeli melalui e-commerce. 
Wanita memiliki niat membeli melalui e-commerce dibandingkan pria. Peranan audio pada Instagram lebih tinggi bagi pendengar di daerah seputar Jakarta (Bodetabek) dibandingkan pendengar di Jakarta.

Perusahaan dapat mengoptimalkan kegiatan promosi melalui Instagram, seperti mengadakan potongan harga, menyebarkan kode diskon atau melakukan sistem reward agar dapat meningkatkan penjualannya melalui e-commerce. Visualisasi gambar pada Instagram perlu ditampilkan secara jelas, dengan tatanan yang menarik dan penggunaan komposisi warna yang sesuai dengan target pasarnya, misalnya dengan menggunakan animasi atau endorser yang sesuai untuk meningkatkan minat beli konsumen. Perusahaan juga perlu memperhatikan informasi yang dicantumkan dalam iklan di Instagram. Informasi yang disediakan harus mudah diingat, mudah dimengerti serta menggambarkan produk dengan jelas.

Penelitian ini dilakukan terbatas pada mahasiswa di Jabodetabek. Penelitian selanjutnya dapat dilakukan pada segmen pasar yang berbeda, baik dari segi geodemografik, psikografik, dan perilaku untuk melihat pengaruh atribut pada Instagram, maupun media sosial lain sehingga dapat memberikan gambaran yang lebih komprehensif sebagai pertimbangan bagi perusahaan untuk mencapai target pasar secara lebih efektif melalui media sosial. Peranan faktor di luar atribut Instagram juga dapat diteliti lebih lanjut, seperti faktor sosial budaya serta motivasi dan persepsi konsumen. Penelitian terhadap iklan di media sosial baru seperti TikTok dan Clubhouse juga dapat menjadi studi yang menarik untuk dikaji. 


\section{DAFTAR PUSTAKA}

Aji, P., Nadhila, V., \& Sanny, L. (2020). Effect of social media marketing on Instagram towards purchase intention: Evidence from Indonesia's ready-to-drink tea industry. International Journal of Data and Network Science, 4(2), 91-104. doi: 10.5267/j.ijdns.2020.3.002

Amornpashara, N., Rompho, N., \& Phadoongsitthi, M. (2015). A study of the relationship between using Instagram and purchase intention. Journal for Global Business Advancement, 8(3), 354370.

Astuti, B., \& Putri, A. P. (2018). Analysis on the effect of Instagram use on consumer purchase intensity. Review of Integrative Business and Economics Research, 7, 24-38.

Chiu, Y. L., Chen, L. J., Du, J., \& Hsu, Y. T. (2018). Studying the relationship between the perceived value of daring group-buying websites and customer loyalty: the moderating role of referral rewards. Journal of Business \& Industrial Marketing, 33(5), 665-679. doi: 10.1108/JBIM-03-2017-0083

Copeland, L. R., \& Zhao, L. (2020). Instagram and theory of reasoned action: US consumers influence of peers daring and purchase intention. International Journal of Fashion Design, Technology and Education, 13(3), 265-279. doi: 10.1080/17543266.2020. 1783374

Erdoğmuş, İ. E., \& Tatar, Ş. B. (2015). Drivers of social commerce through brand engagement. Procedia-Social and Behavioral Sciences, 207, 189-195. doi: 10.1016/ j.sbspro.2015.10.087

Evans, N. J., Phua, J., Lim, J., \& Jun, H. (2017). Disclosing Instagram influencer advertising: The effects of disclosure language on advertising recognition, attitudes, and behavioral intent. Journal of Interactive Advertising, 17(2), 138-149. doi: 10.1080/15252019.2017. 1366885

Gunawan, D. D., \& Huarng, K. H. (2015). Viral effects of social network and media on consumers' purchase intention. Journal of Business Research,68(11), 2237-2241. doi: /10.1016/j.jbusres.2015.06.004

Klabi, F. (2020). Self-image congruity affecting perceived quality and the moderation of brand experience: The case of local and international brands in the Kingdom of Saudi Arabia. Journal of Global Marketing, 33(2), 69-83. doi: 10.1080/08911762.2019. 1614242

Konstantopoulou, A., Rizomyliotis, I., Konstantoulaki, K., \& Badahdah, R. (2019). Improving SMEs' competitiveness with the use of Instagram influencer advertising and eWOM. International Journal of Organizational Analysis, 27(2), 308-321. doi: 10.1108/IJOA-04-2018-1406

Kotler, P. \& Keller, K.L. (2016). Marketing Management (15th ed). New Jersey: Pearson Education.

Kudeshia, C., \& Kumar, A. (2017). Social eWOM: does it affect the brand attitude and purchase intention of brands? Management Research Review, 40(3), 310-330. doi: 10.1108/MRR-072015-0161

Mojambo, G. A., Tulung, J. E., \& Saerang, R. T. (2020). The Influence of Top Management Team (TMT) Characteristics Toward Indonesian Banks Financial Performance During The Digital Era (20142018). JMBI UNSRAT (Jurnal Ilmiah Manajemen Bisnis dan Inovasi Universitas Sam Ratulangi)., 7(1). 
Lee, E., Lee, J. A., Moon, J. H., \& Sung, Y. (2015). Pictures speak louder than words: Motivations for using Instagram. Cyberpsychology, Behavior, and Social Networking, 18(9), 552-556. doi: $10.1089 /$ cyber.2015.0157

Lee, S. H., \& Workman, J. E. (2021). Trendsetting and gender matter: Brand loyalty, perceived quality, and word-of-mouth. Journal of Global Fashion Marketing, 12(1), 16-31. doi: 10.1080/20932685.2020.1835523

Loureiro, S. M. C., \& Sarmento, E. M. (2018). The role of word-of-mouth and celebrity endorsement in daring consumer-brand relationship: the context of Instagram. The role of word-of-mouth and celebrity endorsement in daring consumer-brand relationship: the context of Instagram. Global Marketing Conference at Tokyo Proceedings, 1119-1129, https://doi.org/10.15444/GMC2018.09.05.05 1119-1129.

Rolland, S. E., \& Parmentier, G. (2013). The benefit of social media: Bulletin board focus groups as a tool for co-creation. International Journal of Market Research, 55(6), 809-827. doi: 10.2501/IJMR-2013-068

Sokolova, K., \& Kefi, H. (2020). Instagram and YouTube bloggers promote it, why should I buy? How credibility and parasocial interaction influence purchase intentions. Journal of Retailing and Consumer Services, 53, 101742.

Teo, L. X., Leng, H. K., \& Phua, Y. X. P. (2019). Marketing on Instagram: Social influence and image quality on perception of quality and purchase intention. International Journal of Sports Marketing and Sponsorship, 20(2), 321-332. doi: 10.1108/IJSMS-04-2018-0028

Valentini, C., Romenti, S., Murtarelli, G., \& Pizzetti, M. (2018). Digital visual engagement: influencing purchase intentions on Instagram. Journal of Communication Management, 22(4), 362-381. doi: 10.1108/JCOM-01-2018-0005

Zhu, L., Li, H., Wang, F. K., He, W., \& Tian, Z. (2020). How daring reviews affect purchase intention: a new model based on the stimulus-organism-response (SOR) framework. Aslib Journal of Information Management, 72(4), 463-488. doi: 10.1108/AJIM-11-2019-0308 


\section{Sumber elektronik}

Bisnis.com. (2020). Mantap! Transaksi Ekonomi Digital Indonesia Diproyeksi Bisa Tembus Rp1.748 T di 2025. Diperoleh dari https://ekonomi.bisnis.com/read/20201215/9/ 1331244/mantap-transaksi-ekonomi-digital-indonesia-diproyeksi-bisa-tembus rp 1748-t-di2025

Bisnis.com. (2020b). Efek Pandemi, Transaksi E-Commerce Bakal Melesat Jadi Rp337 Triliun 2021. Diperoleh dari https://ekonomi.bisnis.com/read/20201203/9/1325823/efek-pandemitransaksi-e-commerce-bakal-melesat-jadi-rp337-triliun-2021

CNN Indonesia. (2021). Tokopedia Jadi e-Commerce dengan Kunjungan Tertinggi di RI. Diperoleh dari https:/www.cnnindonesia.com/ekonomi/20210225192546-97-611036/ tokopedia-jadi-e-commerce-dengan-kunjungan-tertinggi-di-ri

Instagram. (2021). Bangun Bisnis Anda di Instagram. Diperoleh dari https://business. instagram.com/advertising?locale $=$ id_ID

Kominfo. (2021). Pengguna Internet di Indonesia 63 Juta Orang. Diperoleh dari https://kominfo.go.id/index.php/content/detail/3415/Kominfo $+\% 3 \mathrm{~A}+$ Pengguna + Internet + di +Indonesia+63+Juta+Orang/0/berita_satker

Lidwina, A. (2019). Infografik: Indonesia Pasar Terbesar E-Commerce di Asia Tenggara. Diperoleh dari https://katadata.co.id/ariayudhistira/infografik/5e9a503b449cd/ infografikindonesia-pasar-terbesar-e-commerce-di-asia-tenggara. 